\title{
PEMANFAATAN CITRA QUICKBIRD DAN SISTEM INFORMASI GEOGRAFIS UNTUK ZONASI KERENTANAN KEBAKARAN PERMUKIMAN KASUS DI KOTA BANDUNG BAGIAN BARAT
}

\author{
Lili Somantri \\ Jurusan Pendidikan Geografi, FPIPS, UPI, \\ L_somantri@ymail.com
}

\begin{abstract}
ABSTRAK
Tujuan penelitian ini adalah 1) mengkaji ketelitian citra Quickbird dalam memperoleh parameter-parameter potensi kebakaran daerah perkotaan untuk menentukan tingkat kerentanan kebakaran permukiman, 2) mengestimasi potensi kebakaran berdasarkan parameter yang diperoleh dari citra Quickbird, 3) memetakan zonasi tingkat kerentanan kebakaran permukiman dengan bantuan Sistem Informasi Geografi. Metode yang digunakan dalam penelitian ini, yaitu interpretasi visual citra penginderaan jauh. Data penginderaan jauh yang digunakan, yaitu citra Quickbird. Uji interpretasi citra Quickbird dilakukan dengan menggunakan metode Short, sedangkan pengolahan dan analisis data menggunakan Sistem Informasi Geografis (SIG) dengan cara pengharkatan (scoring), pembobotan, dan overlay sehingga menghasilkan zonasi kerentanan kebakaran permukiman. Data primer yang digunakan adalah Citra Quickbird Kota Bandung Bagian Barat, hasil survei lapangan, dan data sekunder dari instansi terkait. Variabel untuk zonasi kerentanan kebakaran permukiman dalam penelitian ini terdapat dua variabel utama yaitu, variabel potensi kebakaran dan variabel ketersediaan fasilitas pemadam kebakaran. Variabel potensi kebakaran terdiri atas kepadatan bangunan rumah mukim, pola bangunan rumah mukim, jenis atap bangunan rumah mukim, lokasi sumber air, lokasi permukiman dari jalan utama, lebar jalan masuk, kualitas jalan, kualitas bahan bangunan, dan pelanggan listrik. Adapun variabel ketersediaan fasilitas pemadam kebakaran, yaitu fasilitas air hidran, fasilitas alat pemadam kebakaran ringan $(A P A R)$, alat pemadam kebakaran berat (APAB), dan tandon air. Hasil uji ketelitian interpretasi untuk kepadatan bangunan rumah mukim, yaitu sebesar 92,3\%. Pola bangunan rumah, yaitu sebesar 96,15\%, jenis atap bangunan rumah mukim, yaitu $100 \%$, lebar jalan masuk permukiman, yaitu 100\%, dan kualitas jalan, yaitu 92,3\%. Hasil pemetaan kerentanan kebakaran di daerah penelitian dibagi atas tiga kelas, yaitu rentan, agak rentan, dan tidak rentan. Di daerah penelitian $46,7 \%$ atau seluas 1343,2 Ha termasuk kategori rentan, 30,4\% atau seluas 871,7 Ha termasuk kategori tidak rentan, dan 22,9\% atau seluas 660,1 Ha termasuk kategori agak rentan.
\end{abstract}

Kata Kunci : Citra Quickbird, Sistem Informasi Geografis, Kerentanan Kebakaran permukiman. 


\section{PENDAHULUAN}

Kebakaran adalah bencana yang datangnya tidak terduga dan dapat menimbulkan kerugian harta benda dan korban jiwa, baik perorangan maupun masyarakat. Kebakaran ini merupakan masalah yang terjadi di seluruh dunia, sampai saat ini masih sulit diatasi secara menyeluruh dan tuntas.

Daerah yang rentan terhadap bahaya kebakaran dicirikan oleh kondisi fisik bangunan yang padat, pola bangunan tidak teratur, dan kualitas bangunan rendah, ditambah dengan minimnya fasilitas pemadam kebakaran. Jarak antarrumah yang sempit akan menyulitkan mobil petugas pemadam kebakaran, dan kurang berfungsinya hidran akan memudahkan perembetan api (Suharyadi, 2001).

Mengingat besarnya kerugian yang diakibatkan oleh kebakaran maka perlu diketahui tingkat kerentanan kebakaran permukiman, persebaran maupun luasannya sehingga apabila terjadi kebakaran, penanggulangannya dapat dilakukan secara efektif. Untuk menentukan tingkat kerentanan kebakaran permukiman diperlukan data variabel permukiman yang mempengaruhi kebakaran, seperti kepadatan bangunan rumah mukim, pola bangunan rumah mukim, lebar jalan masuk, dan kualitas jalan. Salah satu teknik yang dapat digunakan untuk mendapatkan data-data tersebut, yaitu melalui penginderaan jauh.

Salah satu citra satelit yang saat ini banyak digunakan untuk studi perkotaan adalah citra Quickbird. Keunggulan citra Quickbird memiliki resolusi spasial yang sangat tinggi, yaitu 0,6 meter sehingga menyajikan ketelitian data cukup akurat. Resolusi setinggi ini dapat digunakan untuk mengidentifikasi permukiman dengan baik. Menurut Gunawan (2005) data perkotaan yang dapat disadap dari citra Quickbird meliputi data kepadatan rumah, data permukiman kumuh (slump area), drainase kota, topografi yang dapat disusun dalam bentuk basis data. Menurut Naibaho (2004) jaringan jalan sebagai salah satu bagian infrastruktur terpenting di perkotaan yang berfungsi untuk menghubungkan antara tempat yang satu dan tempat lainnya dapat diidentifikasi dengan menggunakan citra Quickbird. Selanjutnya Danoedoro (2003) menjelaskan bahwa resolusi spasial tinggi ditujukan untuk mendukung aplikasi kekotaan, seperti pengenalan pola permukiman, perkembangan dan perluasan daerah terbangun. Berdasarkan citra Quickbird dapat dilihat jenis atap bangunan, misalnya genteng tanah liat, asbes, beton yang dicat hingga perbedaan warna tanah.

Sistem Informasi Geografis (SIG) sebagai salah satu pengembangan dari bentuk sistem memiliki fungsi sebagai alat bantu dalam pemetaan. SIG sangat dibutuhkan dalam pengolahan dan analisis data faktor-faktor yang mempengaruhi kerentanan kebakaran permukiman sehingga menghasilkan informasi baru, yaitu berupa peta zonasi kerentanan kebakaran permukiman. 


\section{METODE PENELITIAN}

Metode yang digunakan, yaitu interpretasi citra penginderaan jauh. Teknik interpretasi dilakukan secara visual pada citra Quickbird, dimana mengenali objek berdasarkan unsur-unsur interpretasi. Untuk pengolahan dan analisis data menggunakan Sistem Informasi Geografis (SIG) dengan cara pengharkatan (scoring), pembobotan, dan overlay. Data yang digunakan, yaitu Citra Quickbird Pankromatik tanggal 21 Agustus 2003 Daerah Kota Bandung Bagian Barat dengan resolusi spasial 0,6 meter.

Untuk menentukan zonasi kerentanan kebakaran permukiman terdapat dua variabel utama, yaitu variabel potensi kebakaran dan variabel ketersediaan fasilitas pemadam kebakaran. Variabel potensi kebakaran terdiri atas kepadatan bangunan rumah mukim, pola bangunan rumah mukim, jenis atap bangunan rumah mukim, lokasi sumber air, lokasi permukiman dari jalan utama, lebar jalan masuk, kualitas jalan, kualitas bahan bangunan, dan pelanggan listrik. Adapun variabel ketersediaan fasilitas pemadam kebakaran, yaitu fasilitas air hidran, fasilitas alat pemadam kebakaran ringan (APAR), alat pemadam kebakaran berat (APAB), dan tandon air.

Data kepadatan bangunan rumah mukim, pola bangunan rumah mukim, jenis atap bangunan rumah mukim, lokasi sumber air, lokasi permukiman dari jalan utama, lebar jalan masuk, dan kualitas jalan diperoleh dari citra Quickbird. Data pelanggan listrik, hidran, tandon air, APAR, dan APAB diperoleh dari data sekunder. Data jenis bahan bangunan diperoleh dari survei lapangan.

Untuk menentukan tingkat kerentanan kebakaran berdasarkan potensi kebakaran permukiman dan fasilitas pemadam kebakaran dilakukan melalui pendekatan kuantitatif, yaitu pengharkatan tertimbang. Pendekatan tersebut dilakukan dengan memberi harkat atau nilai pada setiap variabel yang akan digunakan, dan masing-masing variabel diberikan nilai bobot atau faktor penimbangnya. Untuk memadukan antara potensi kebakaran permukiman dan fasilitas pemadam kebakaran dilakukan dengan matriks dua dimensi. Nilai harkat dan bobot setiap parameter yang mempengaruhi kerentanan kebakaran dapat dilihat pada Tabel 1.

Tabel 1

Nilai Harkat dan Bobot Parameter Kerentanan Kebakaran Permukiman

\begin{tabular}{|c|c|c|c|c|}
\hline VARIABEL & $\begin{array}{l}\text { PARAMETER } \\
\text { KERENTANAN } \\
\text { KEBAKARAN }\end{array}$ & KELAS & HARKAT & ВОВОТ \\
\hline \multirow{4}{*}{$\begin{array}{l}\text { Potensi } \\
\text { Kebakaran }\end{array}$} & \multicolumn{4}{|c|}{$\begin{array}{l}\text { 1. Kepadatan Bangunan Rumah Mukim (Persentase Blok Permukiman Berdasarkan } \\
\text { Kepadatan Bangunan Rata-Rata) }\end{array}$} \\
\hline & a.Jarang & $<40 \%$ & \begin{tabular}{|l|}
1 \\
\end{tabular} & \multirow{3}{*}{3} \\
\hline & b.Agak Padat & $40 \%-75 \%$ & 2 & \\
\hline & c.Padat & $>75 \%$ & 3 & \\
\hline
\end{tabular}




\begin{tabular}{|c|c|c|c|c|}
\hline & Teratur & $>75 \%$ & 1 & \multirow{3}{*}{2} \\
\hline & Agak Teratur & $40 \%-75 \%$ & 2 & \\
\hline & Tidak Teratur & $<40 \%$ & 3 & \\
\hline & \multicolumn{4}{|c|}{$\begin{array}{l}\text { 3. Jenis Atap Bangunan Rumah Mukim (Persentase Blok Permukiman Berdasarkan Jenis } \\
\text { Atap Genteng dan Beton) }\end{array}$} \\
\hline & Baik & $>75 \%$ & 1 & \multirow{3}{*}{2} \\
\hline & Sedang & $40 \%-75 \%$ & 2 & \\
\hline & Buruk & $<40 \%$ & 3 & \\
\hline & \multicolumn{4}{|c|}{ 4. Lokasi Permukiman dari Jalan Utama (Persentase Blok Permukiman dari Jalan Utama) } \\
\hline & Dekat & $>75 \%$ berjarak $100 \mathrm{~m}$ & 1 & \multirow{3}{*}{3} \\
\hline & Agak Jauh & $\begin{array}{l}40 \%-75 \% \text { berjarak } 100 \mathrm{~m} \\
\text { dan }>75 \% \text { berjarak } 100-200 \mathrm{~m}\end{array}$ & 2 & \\
\hline & Jauh & $\begin{array}{l}<40 \% \text { berjarak } 100 \mathrm{~m} \\
\text { dan }<75 \% \text { berjarak } 100-200 \mathrm{~m}\end{array}$ & 3 & \\
\hline & \multicolumn{4}{|c|}{$\begin{array}{l}\text { 5.Lokasi Permukiman dari Sumber Air (Persentase Blok Permukiman Terhadap Buffer } \\
\text { Jarak Lokasi Sumber Air) }\end{array}$} \\
\hline & Dekat & $>75 \%$ Berjarak kurang dari $500 \mathrm{~m}$ & 1 & \multirow{3}{*}{3} \\
\hline & Sedang & $\begin{array}{l}40 \%-75 \% \text { Berjarak kurang dari } 500 \mathrm{~m} \\
\text { dan }>75 \% \text { Berjarak antara } 500 \mathrm{~m}-2.000 \mathrm{~m}\end{array}$ & 2 & \\
\hline & Jauh & $\begin{array}{l}<40 \% \text { Berjarak kurang dari } 500 \mathrm{~m} \text { dan } \\
<75 \% \text { Berjarak antara } 500 \mathrm{~m}-2.000 \mathrm{~m}\end{array}$ & 3 & \\
\hline & \multicolumn{4}{|c|}{ 6. Lebar Jalan Masuk (Persentase Blok Permukiman terhadap Lebar Jalan Masuk) } \\
\hline & Lebar & $>75 \%$ Lebarnya masuknya lebih dari $6 \mathrm{~m}$ & 1 & \multirow{3}{*}{3} \\
\hline & Agak Lebar & $\begin{array}{l}40 \%-75 \% \text { Lebarnya masuknya lebih dari } 6 \mathrm{~m} \\
\text { dan }>75 \% \text { Lebarnya masuknya antara } 3 \mathrm{~m}-6 \mathrm{~m}\end{array}$ & 2 & \\
\hline & Sempit & $\begin{array}{l}<40 \% \text { Lebarnya masuknya lebih dari } 6 \mathrm{~m} \text { dan } \\
<75 \% \text { Lebarnya masuknya antara } 3 \mathrm{~m}-6 \mathrm{~m}\end{array}$ & 3 & \\
\hline & \multicolumn{4}{|c|}{$\begin{array}{l}\text { 7. Kualitas Jalan (Persentase Blok Permukiman Terhadap Jalan yang Telah Diperkeras } \\
\text { Aspal, Beton, Tembok) }\end{array}$} \\
\hline & Baik & $>75 \%$ & 1 & \multirow{3}{*}{2} \\
\hline & Sedang & $40 \%-75 \%$ & 2 & \\
\hline & Buruk & $<40 \%$ & 3 & \\
\hline & \multicolumn{4}{|c|}{$\begin{array}{l}\text { 8. Jenis Bahan Bangunan (Persentase Blok Permukiman Terhadap Kualitas Bahan } \\
\text { Bangunan Beton, Bata, Batako) }\end{array}$} \\
\hline & $\begin{array}{l}\text { Tidak Mudah } \\
\text { Terbakar }\end{array}$ & $>75 \%$ & 1 & \multirow{3}{*}{3} \\
\hline & $\begin{array}{l}\text { Agak Mudah } \\
\text { Terbakar }\end{array}$ & $40 \%-75 \%$ & 2 & \\
\hline & Mudah Terbakar & $<40 \%$ & 3 & \\
\hline & \multicolumn{4}{|c|}{ 9. Pelanggan Listrik (Persentase Blok Permukiman yang Berlangganan Listrik Ke PLN) } \\
\hline & Baik & $>50 \%$ & 1 & \multirow{3}{*}{3} \\
\hline & Sedang & $25 \%-50 \%$ & 2 & \\
\hline & Buruk & $<25 \%$ & 3 & \\
\hline \multirow{5}{*}{$\begin{array}{l}\text { Fasilitas } \\
\text { Pemadam } \\
\text { Kebakaran }\end{array}$} & $\begin{array}{l}\text { 10. Fasilitas Hidra } \\
\text { Hidran }(<500 \text { Met }\end{array}$ & Persentase Blok Permukiman yang Mudah Terla & i ole & as Air \\
\hline & Baik & $>75 \%$ Berjarak kurang dari $500 \mathrm{~m}$ & 1 & \multirow{3}{*}{2} \\
\hline & Sedang & $\begin{array}{l}40 \%-75 \% \text { Berjarak kurang dari } 500 \mathrm{~m} \\
\text { dan }>75 \% \text { Berjarak antara } 500 \mathrm{~m}-1.000 \mathrm{~m}\end{array}$ & 2 & \\
\hline & Buruk & $\begin{array}{l}<40 \% \text { Berjarak kurang dari } 500 \mathrm{~m} \\
\text { dan }<75 \% \text { Berjarak antara } 500 \mathrm{~m}-1.000 \mathrm{~m}\end{array}$ & 3 & \\
\hline & \multicolumn{4}{|c|}{ 11. Fasilitas APAR (Persentase Blok Permukiman yang Dilengkapi dengan Fasilitas APAR } \\
\hline
\end{tabular}




\begin{tabular}{|c|c|c|c|}
\hline Lengkap & $>50 \%$ & 1 & \multirow{3}{*}{1} \\
\hline Agak Lengkap & $1 \%-50 \%$ & 2 & \\
\hline Tidak Lengkap & $<1 \%$ & 3 & \\
\hline \multicolumn{4}{|c|}{ 12. Fasilitas APAB (Persentase Blok Permukiman Yang Dilengkapi Dengan Fasilitas APAB) } \\
\hline Lengkap & $>50 \%$ & 1 & \multirow{3}{*}{1} \\
\hline Agak Lengkap & $1 \%-50 \%$ & 2 & \\
\hline Tidak Lengkap & $<1 \%$ & 3 & \\
\hline \multicolumn{4}{|c|}{$\begin{array}{l}\text { 13. Fasilitas Tandon Air (Persentase Blok Permukiman yang Mudah Terlayani oleh Fasilitas } \\
\text { Tandon Air }<500 \text { Meter) }\end{array}$} \\
\hline Dekat & $>75 \%$ Berjarak kurang dari $500 \mathrm{~m}$ & 1 & \multirow{3}{*}{2} \\
\hline Sedang & $\begin{array}{l}40 \%-75 \% \text { Berjarak kurang dari } 500 \mathrm{~m} \\
\text { dan }>75 \% \text { Berjarak antara } 500 \mathrm{~m}-2.000 \mathrm{~m}\end{array}$ & 2 & \\
\hline Jauh & $\begin{array}{l}<40 \% \text { Berjarak kurang dari } 500 \mathrm{~m} \\
\text { dan }<75 \% \text { Berjarak antara } 500 \mathrm{~m}-1.000 \mathrm{~m}\end{array}$ & 3 & \\
\hline
\end{tabular}

Sumber: Ditjen Cipta Karya, 1980; Suharyadi, 2000 dengan perubahan.

Potensi kebakaran permukiman pada setiap satuan pemetaan (blok permukiman) ditentukan dengan cara menjumlahkan harkat atau nilai setiap parameter yang digunakan sebagai penilai setelah dikalikan dengan faktor pembobotnya. Formula pemodelan tersebut, yaitu sebagai berikut.

$\mathrm{PK}=\sum_{\mathrm{i}=1}^{\mathrm{n}} \mathrm{V}_{\mathrm{i}} \mathrm{B}_{\mathrm{i}}$

Keterangan:

PK = Harkat total potensi kebakaran

$\mathrm{n} \quad=$ Jumlah parameter

$\mathrm{Vi} \quad=$ Variabel potensi kebakaran

$\mathrm{Bi} \quad=$ Faktor pembobot variabel potensi kebakaran

Harkat potensi kebakaran yang dihasilkan dari formula tersebut nilainya bervariasi. Untuk memudahkan dalam analisis harkat total, setiap satuan pemetaan diklasifikasikan. Klasifikasi potensi kebakaran dibagi menjadi tiga kelas, yaitu potensi rendah, sedang, dan tinggi.

Untuk menentukan kualitas fasilitas pemadam kebakaran yang ada pada setiap blok permukiman dilakukan dengan cara menjumlahkan harkat parameter yang digunakan setelah dikalikan dengan faktor pembobotnya. Formula yang digunakan adalah sebagai berikut.

$$
F P=\sum_{i=1}^{n} V_{i} B_{i}
$$

\section{Keterangan:}

FP $\quad$ = Harkat total fasilitas pemadam kebakaran

$\mathrm{n} \quad=$ Jumlah parameter

$\mathrm{Vi} \quad=$ Variabel fasilitas pemadam kebakaran

$\mathrm{Bi} \quad=$ Faktor pembobot variabel fasilitas pemadam kebakaran 
Harkat variabel fasilitas pemadam kebakaran juga nilainya bervariasi. Klasifikasi fasilitas pemadam kebakaran dibagi menjadi tiga kelas, yaitu baik, sedang, dan buruk. Hasil pemodelan pada tahap pertama, yaitu peta potensi kebakaran dan peta fasilitas pemadam kebakaran. Kedua peta tersebut digabungkan (overlay) sehingga menghasilkan peta akhir, yaitu peta zonasi kerentanan kebakaran permukiman. Kelas kerentanan kebakaran permukiman dibedakan atas tiga kategori, tidak rentan, agak rentan, dan rentan. Penentuan zonasi kerentanan kebakaran menggunakan tabel dua dimensi sebagai berikut.

Tabel 2.

Kelas Kerentanan Kebakaran Permukiman

\begin{tabular}{cccc}
\hline KELAS & \multicolumn{3}{c}{ KELAS FASILITAS PEMADAM KEBAKARAN } \\
\cline { 2 - 4 } POTENSI KEBAKARAN & Baik & Sedang & Buruk \\
\hline Rendah & Tidak Rentan & Tidak Rentan & Agak Rentan \\
\hline Sedang & Agak Rentan & Rentan & Rentan \\
\hline Tinggi & Rentan & Rentan & Rentan \\
\hline
\end{tabular}

Sumber : Hasil Analisis, 2008.

\section{HASIL DAN PEMBAHASAN}

\section{Uji Ketelitian Hasil Interpretasi}

Uji ketelitian ini dilakukan terhadap 26 blok permukiman sebagai sampel dari jumlah keseluruhan, yaitu 111 blok permukiman. Hasil uji ketelitian interpretasi untuk kepadatan bangunan rumah mukim, yaitu sebesar 92,3\% yang dapat dilihat pada Tabel 3 berikut.

Tabel 3.

Matrik Uji Ketelitian Interpretasi Kepadatan Bangunan Rumah Mukim

\begin{tabular}{|c|c|c|c|c|c|c|c|}
\hline \multirow{2}{*}{$\begin{array}{l}\text { Pengukuran } \\
\text { Lapangan }\end{array}$} & \multicolumn{3}{|c|}{ Interpretasi Citra Quickbird } & \multirow[t]{2}{*}{ Jumlah } & \multirow{2}{*}{$\begin{array}{c}\text { Omisi } \\
(\%)\end{array}$} & \multirow{2}{*}{$\begin{array}{c}\text { Komisi } \\
(\%)\end{array}$} & \multirow{2}{*}{$\begin{array}{c}\text { Ketelitian } \\
\text { Interpretasi } \\
(\%)\end{array}$} \\
\hline & Jarang & $\begin{array}{l}\text { Agak } \\
\text { Padat }\end{array}$ & Padat & & & & \\
\hline Jarang & 3 & 1 & - & 4 & 25 & 0 & 75 \\
\hline Agak Padat & - & 9 & - & 9 & 0 & 0 & 100 \\
\hline Padat & - & 1 & 12 & 13 & 0 & 7,7 & 92,3 \\
\hline Jumlah & 3 & 11 & 12 & 26 & & & \\
\hline
\end{tabular}

Sumber : Hasil Interpretasi dan Cek Lapangan Januari 2008

Uji ketelitan hasil interpretasi $=\frac{3+9+12}{26} \times 100 \%$

$$
=92,3 \%
$$

Pola bangunan rumah mukim ditentukan berdasarkan kesejajaran antarbangunan dan berdasarkan letaknya terhadap posisi jalan, baik jalan lokal maupun jalan kolektor. Hasil uji ketelitian interpretasi keseluruhan untuk pola bangunan rumah, yaitu sebesar $96,15 \%$ yang dapat dilihat pada Tabel 4 berikut. 
Tabel 4.

Matrik Uji Ketelitian Interpretasi Pola Bangunan Rumah Mukim

\begin{tabular}{ccccccccc}
\hline $\begin{array}{c}\text { Pengukuran } \\
\text { Lapangan }\end{array}$ & \multicolumn{2}{c}{ Interpretasi Citra Quickbird } & Jumlah & $\begin{array}{c}\text { Omisi } \\
(\%)\end{array}$ & $\begin{array}{c}\text { Komisi } \\
(\%)\end{array}$ & $\begin{array}{c}\text { Ketelitian } \\
\text { Interpretasi } \\
(\%)\end{array}$ \\
\hline Teratur & $\begin{array}{c}\text { Agak } \\
\text { Teratur }\end{array}$ & $\begin{array}{c}\text { Tidak } \\
\text { Teratur }\end{array}$ & & - & & & \\
\hline $\begin{array}{c}\text { Agak } \\
\text { Teratur }\end{array}$ & 7 & - & 8 & - & 7 & 0 & 0 & 100 \\
\hline $\begin{array}{c}\text { Tidak } \\
\text { Teratur }\end{array}$ & - & 1 & 10 & 11 & 9,1 & 0 & 90,9 \\
\hline Jumlah & 7 & 9 & 11 & 26 & & & \\
\hline
\end{tabular}

Sumber : Hasil Interpretasi dan Cek Lapangan Januari 2008

Uji ketelitan hasil interpretasi $=\frac{7+8+10}{26} \times 100 \%$

$$
=96,15 \%
$$

Interpretasi jenis atap mudah dikenali citra Quickbird karena sesuai dengan warna aslinya. Prosentase jenis atap merupakan hasil perbandingan jenis atap tertentu terhadap jenis atap keseluruhan. Berdasarkan uji ketelitian, hasil interpretasi secara keseluruhan, yaitu 100\% yang dapat dilihat pada Tabel 5 .

Tabel 5.

Matrik Uji Ketelitian Interpretasi Jenis Atap Bangunan Rumah Mukim

\begin{tabular}{|c|c|c|c|c|c|c|c|}
\hline \multirow{2}{*}{$\begin{array}{c}\text { Pengukuran } \\
\text { Lapangan }\end{array}$} & \multicolumn{3}{|c|}{ Interpretasi Citra Quickbird } & \multirow[t]{2}{*}{ Jumlah } & \multirow{2}{*}{$\begin{array}{c}\text { Omisi } \\
(\%)\end{array}$} & \multirow{2}{*}{$\begin{array}{c}\text { Komisi } \\
(\%)\end{array}$} & \multirow{2}{*}{$\begin{array}{l}\text { Ketelitian } \\
\text { Interpretasi } \\
(\%)\end{array}$} \\
\hline & Baik & Sedang & Buruk & & & & \\
\hline Baik & 17 & - & - & 17 & 0 & 0 & 100 \\
\hline Sedang & - & 9 & - & 9 & 0 & 0 & 100 \\
\hline Buruk & - & - & - & - & & & \\
\hline Jumlah & 17 & 9 & - & 26 & & & \\
\hline
\end{tabular}

Sumber : Hasil Interpretasi dan Cek Lapangan Januari 2008

Uji ketelitan hasil interpretasi $=\frac{17+9}{26} \times 100 \%$

$$
=100 \%
$$

Lebar jalan masuk ditunjukkan dengan keberadaan jalan yang menghubungkan blok permukiman dengan blok permukiman lain atau dengan jalan utama. ketelitian hasil interpretasi secara keseluruhan, yaitu $100 \%$. Tingginya ketelitian lebar jalan karena objek jalan sangat mudah dikenali dari citra Quickbird terutama jalan kolektor dan jalan lokal. Untuk lebih jelas mengenai ketelitian lebar jalan masuk dapat dilihat pada Tabel 6. 
Tabel 6.

Matrik Uji Ketelitian Interpretasi Lebar Jalan Masuk Permukiman

\begin{tabular}{|c|c|c|c|c|c|c|c|}
\hline \multirow{2}{*}{$\begin{array}{l}\text { Pengukuran } \\
\text { Lapangan }\end{array}$} & \multicolumn{3}{|c|}{ Interpretasi Citra Quickbird } & \multirow[t]{2}{*}{ Jumlah } & \multirow{2}{*}{$\begin{array}{l}\text { Omisi } \\
(\%)\end{array}$} & \multirow{2}{*}{$\begin{array}{c}\text { Komisi } \\
(\%)\end{array}$} & \multirow{2}{*}{$\begin{array}{c}\text { Ketelitian } \\
\text { Interpretasi } \\
(\%)\end{array}$} \\
\hline & Lebar & $\begin{array}{l}\text { Agak } \\
\text { Lebar }\end{array}$ & Sempit & & & & \\
\hline Lebar & 12 & - & - & 12 & 0 & 0 & 100 \\
\hline Agak Lebar & - & 5 & - & 5 & 0 & 0 & 100 \\
\hline Sempit & - & - & 9 & 9 & 0 & 0 & 100 \\
\hline Jumlah & 12 & 5 & 9 & 26 & & & \\
\hline
\end{tabular}

Sumber : Hasil Interpretasi dan Cek Lapangan Januari 2008

Uji ketelitan hasil interpretasi $=\frac{12+5+9}{26} \times 100 \%=100 \%$

Kualitas jalan berkaitan dengan baik buruknya kondisi jalan, seperti jalan beraspal, beton, tembok, berbatu, atau masih berupa tanah. Berdasarkan uji ketelitian, ketelitian hasil interpretasi secara keseluruhan, yaitu 92,3\%.

Tabel 7.

Matrik Uji Ketelitian Interpretasi Kualitas Jalan Permukiman

\begin{tabular}{|c|c|c|c|c|c|c|c|}
\hline \multirow{2}{*}{$\begin{array}{c}\text { Pengukuran } \\
\text { Lapangan }\end{array}$} & \multicolumn{3}{|c|}{ Interpretasi Citra Quickbird } & \multirow[t]{2}{*}{ Jumlah } & \multirow{2}{*}{$\begin{array}{l}\text { Omisi } \\
(\%)\end{array}$} & \multirow{2}{*}{$\begin{array}{c}\text { Komisi } \\
(\%)\end{array}$} & \multirow{2}{*}{$\begin{array}{c}\text { Ketelitian } \\
\text { Interpretasi } \\
(\%)\end{array}$} \\
\hline & Baik & Agak Baik & Buruk & & & & \\
\hline Baik & 14 & 1 & - & 15 & 6,6 & 0 & 93,3 \\
\hline Agak Baik & - & 7 & 1 & 8 & 12,5 & 12,5 & 87,5 \\
\hline Buruk & - & - & 3 & 3 & 0 & 0 & 100 \\
\hline Jumlah & 14 & 8 & 4 & 26 & & & \\
\hline
\end{tabular}

Sumber : Hasil Interpretasi dan Cek Lapangan Januari 2008

Uji ketelitan hasil interpretasi $=\frac{14+7+3}{26} \times 100 \%=92,3 \%$

Kondisi jalan dapat dilihat dari ronanya, jalan yang beraspal akan berona agak gelap, sedangkan jalan yang dibeton atau ditembok ronanya abu-abu. Jalan berbatu memiliki rona yang cerah dengan tekstur kasar, dan jalan yang masih tanah berwarna kecokelatan.

\section{Pemetaan Potensi Kebakaran}

Pemetaan zonasi kerentanan kebakaran permukiman dilakukan dengan mempertimbangkan faktor potensi kebakaran dan faktor fasilitas pemadam kebakaran. Pemetaan potensi kebakaran didasarkan atas penilaian parameter kepadatan bangunan rumah mukim, pola bangunan rumah mukim, lokasi blok permukiman dari jalan utama, jenis atap bangunan rumah mukim, lebar jalan masuk permukiman, kualitas jalan, lokasi sumber air, kualitas bahan bangunan permukiman, dan pelanggan listrik. Peta potensi kebakaran diperoleh dengan 
menggunakan analisis SIG software arcGis, yaitu dengan mengoverlaykan kesembilan peta tersebut.

Parameter-parameter tersebut diperoleh dari hasil ekstraksi citra Quickbird, data sekunder, dan survei lapangan. Masing-masing parameter diberi bobot berdasarkan pengaruhnya terhadap kerentanan kebakaran permukiman. Parameter yang sangat berpengaruh diberi bobot 3 , dan yang kurang berpengaruh diberi bobot 1 , sebelumnya setiap parameter diberikan harkat 1 sampai 3 .

Setelah diperhitungkan harkat dan bobotnya maka dihasilkan harkat total, nilai totalnya mendekati distribusi normal dan pengkelasannya yang dipakai adalah equal interval. Dengan klasifikasi sebagai berikut.

Tabel 8.

Tabel Klasifikasi Potensi Kebakaran

\begin{tabular}{|c|c|c|}
\hline $\mathrm{NO}$ & KELAS & HARKAT TOTAL \\
\hline 1 & Rendah & $28-39$ \\
\hline 2 & Sedang & $40-50$ \\
\hline 3 & Tinggi & $51-61$ \\
\hline
\end{tabular}

Luas dan persentase persebaran potensi kebakaran permukiman disajikan pada Tabel 9 sedangkan petanya dapat dilihat pada Gambar 1.

Tabel 9.

Kelas Potensi Kebakaran Permukiman

\begin{tabular}{llcccc}
\hline \multirow{2}{*}{ NO } & \multirow{2}{*}{ KECAMATAN } & \multicolumn{2}{c}{ KELAS POTENSI KEBAKARAN } & \multirow{2}{*}{ LUAS } \\
\cline { 3 - 5 } & & \multicolumn{2}{c}{ PERMUKIMAN (HA) } & TOTAL \\
\cline { 3 - 5 } & Rendah & Sedang & Tinggi & \\
\hline 1 & Coblong & 124,4 & 138,5 & 199,2 & 462,1 \\
\hline 2 & Sukasari & 303,5 & 35,9 & 34,7 & 374,2 \\
\hline 3 & Cidadap & 149,1 & 53 & 24,7 & 226,9 \\
\hline 4 & Bojongloa Kaler & 0 & 17,1 & 195,1 & 212,2 \\
\hline 5 & Babakan Ciparay & 134,4 & 96,6 & 116,1 & 347,1 \\
\hline 6 & Andir & 49,5 & 37,7 & 140,3 & 227,5 \\
\hline 7 & Cicendo & 107,8 & 133,2 & 65,4 & 306,5 \\
\hline 8 & Bandung Kulon & 71,9 & 147,3 & 106,1 & 325,3 \\
\hline 9 & Sukajadi & 206,3 & 31,8 & 155 & 393,1 \\
\hline & Jumlah & 1146,9 & 691,3 & 1036,7 & 2875 \\
\hline & Prosentase & 39,9 & 24 & 36,1 & 100 \\
\hline
\end{tabular}

Sumber: Hasil Pengolahan, 2008.

Berdasarkan data pada Tabel 9, dapat diketahui bahwa sebanyak 36,1\% atau 1036,7 Ha termasuk pada kelas tinggi, 24\% atau 691,3 Ha termasuk pada kelas sedang, dan 39,9\% atau 1146,9 Ha termasuk pada kelas potensi rendah. 


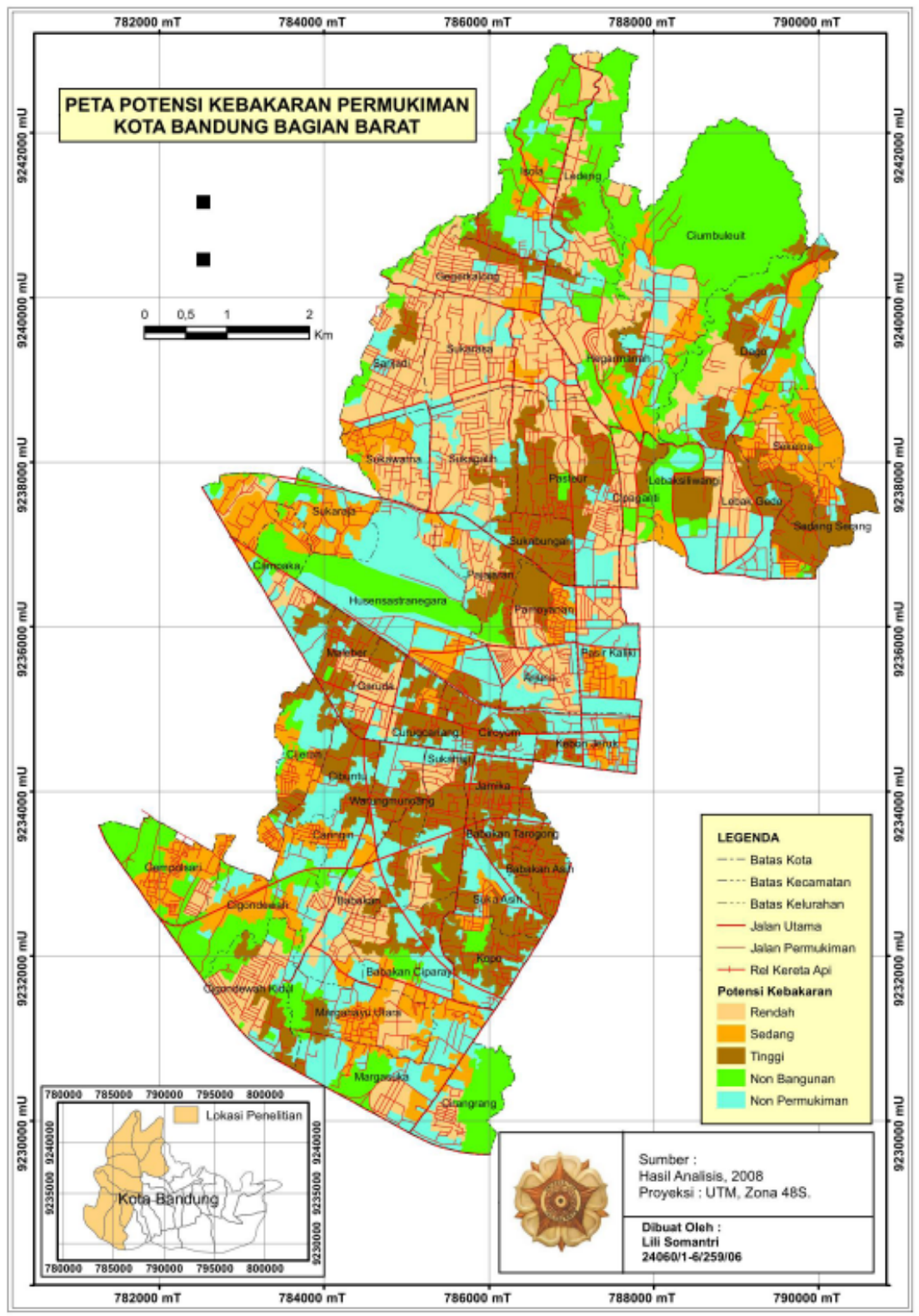

Gambar 1 Peta Potensi Kebakaran Permukiman

Jika dilihat per kecamatan, yang memiliki potensi tinggi paling luas, yaitu Coblong (199,2 Ha), Bojongloa Kaler (195,1 Ha), dan Sukajadi (155 Ha). Kecamatan yang memiliki potensi sedang paling luas, yaitu Bandung Kulon (147,3 Ha), Coblong (138,5 Ha), dan Cicendo (133,2 Ha), kecamatan yang memiliki potensi rendah paling luas, Sukasari (303,5 Ha), Sukajadi (206,3 Ha), dan Cidadap (149,1 Ha). 


\section{Pemetaan Fasilitas Pemadam Kebakaran}

Fasilitas pemadam kebakaran digunakan untuk mencegah dan menanggulangi kebakaran yang lebih besar dan meminimalkan dampak kerugian maupun korban yang disebabkan oleh kebakaran tersebut. Oleh karena itu, fasilitas pemadam kebakaran perlu dipetakan yang didasarkan atas penilaian terhadap ketersediaan fasilitas hidran, APAR, APAB, dan tandon air.

Parameter fasilitas pemadam kebakaran diperoleh dari data sekunder, dan hasil survei lapangan. Masing-masing parameter diberi bobot berdasarkan pengaruhnya terhadap kerentanan kebakaran permukiman. Parameter yang sangat berpengaruh diberi bobot 3 , yang agak berpengaruh 2 , dan yang kurang berpengaruh diberi bobot 1 , sebelumnya setiap parameter diberikan harkatnya, 1 sampai 3. Setelah diperhitungkan harkat dan bobotnya teknik overlay maka dihasilkan harkat total, nilai totalnya mendekati distribusi normal dengan klasifikasi sebagai berikut.

Tabel 10.

\begin{tabular}{|c|c|c|}
\hline $\mathrm{NO}$ & KELAS & HARKAT TOTAL \\
\hline 1 & Baik & $9-13$ \\
\hline 2 & Sedang & $14-17$ \\
\hline 3 & Buruk & $18-21$ \\
\hline
\end{tabular}

Sumber : Hasil perhitungan, 2008.

Luas dan persentase persebaran fasilitas pemadam kebakaran disajikan pada Tabel 11, sedangkan petanya dapat dilihat pada Gambar 2.

Tabel 11.

Luas Blok Permukiman Berdasarkan Fasilitas Pemadam Kebakaran

\begin{tabular}{|c|c|c|c|c|c|}
\hline \multirow[t]{2}{*}{$\mathrm{NO}$} & \multirow[t]{2}{*}{ KECAMATAN } & \multicolumn{3}{|c|}{ LUAS BLOK BERDASARKAN FASILITAS (HA) } & \multirow{2}{*}{$\begin{array}{r}\text { LUAS } \\
\text { TOTAL }\end{array}$} \\
\hline & & Baik & Sedang & Buruk & \\
\hline 1 & Coblong & 198 & 68,4 & 195,7 & 462,1 \\
\hline 2 & Sukasari & 38,9 & 51,8 & 283,5 & 374,2 \\
\hline 3 & Cidadap & 30,1 & 94,9 & 101,9 & 226,9 \\
\hline 4 & Bojongloa Kaler & 0 & 210,9 & 1,2 & 212,2 \\
\hline 5 & Babakan Ciparay & 0 & 289,4 & 57,7 & 347,1 \\
\hline 6 & Andir & 0 & 183,3 & 44,2 & 227,5 \\
\hline 7 & Cicendo & 97,8 & 160,9 & 47,7 & 306,5 \\
\hline 8 & Bandung Kulon & 0 & 314,7 & 10,6 & 325,3 \\
\hline 9 & Sukajadi & 71,3 & 0 & 321,8 & 393,1 \\
\hline & Jumlah & 436,1 & 1374,4 & 1064,4 & 2875 \\
\hline & Prosentase & 15 & 47,8 & 37 & 100 \\
\hline
\end{tabular}

Sumber: Hasil Pengolahan, 2008.

Berdasarkan data pada Tabel 11, tersebut dapat diketahui bahwa sebanyak $47,8 \%$ atau $1374,4 \mathrm{Ha}$ fasilitasnya termasuk kategori sedang, $37 \%$ atau $1064,4 \mathrm{Ha}$ termasuk pada kelas buruk, $15 \%$ atau 436,1 Ha termasuk pada kelas baik. Jika dilihat per kecamatan, yang memiliki fasilitas baik paling luas, yaitu Coblong 
(198 Ha), Cicendo (97,8 Ha), dan Sukajadi (71,3 Ha). Kecamatan yang memiliki fasilitas kategori sedang paling luas, Bandung Kulon (314,7 Ha), Babakan Ciparay (289,4 Ha), dan Bojongloa Kaler (210,9 Ha). Kecamatan yang memiliki fasilitas kategori buruk paling luas, yaitu Sukajadi (321,8 Ha), Sukasari (283,5 Ha), dan Coblong (195,7 Ha).

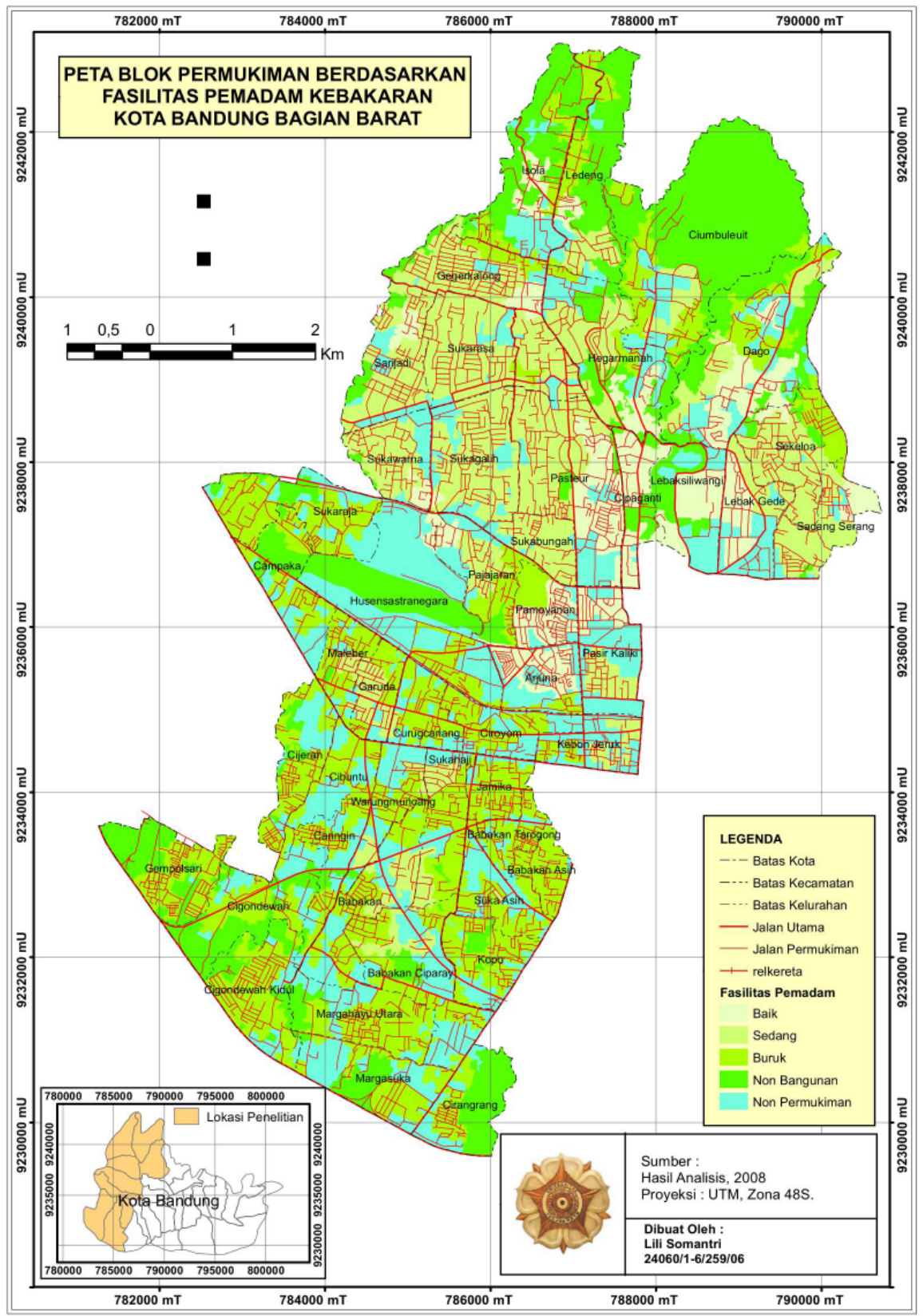

Gambar 2 Peta Ketersediaan Fasilitas Pemadam Kebakaran 


\section{Pemetaan Zonasi Kerentanan Kebakaran Permukiman}

Peta zonasi kerentanan kebakaran permukiman merupakan hasil akhir dari penelitian ini. Peta ini didasarkan atas peta potensi kebakaran dan peta fasilitas pemadam kebakaran, dengan mengoverlaykan kedua peta tersebut dengan kemudian dikelaskan dengan menggunakan tabel dua dimensi. Berikut adalah data luas daerah kerentanan kebakaran permukiman berdasarkan kecamatan di Kota Bandung Bagian Barat.

Tabel 12.

Luas Blok Permukiman Berdasarkan Kelas Kerentanan Kebakaran

\begin{tabular}{llcccc}
\hline NO & KECAMATAN & \multicolumn{2}{c}{ LUAS BLOK BERDASARKAN FASILITAS } & LUAS TOTAL \\
\cline { 3 - 5 } & & $\begin{array}{c}\text { THA }) \\
\text { Rentan }\end{array}$ & Agak Rentan & Rentan & \\
\hline 1 & Coblong & 124,4 & 174,5 & 163,3 & 462,1 \\
\hline 2 & Sukasari & 281,7 & 62,5 & 30,1 & 374,3 \\
\hline 3 & Cidadap & 101,9 & 77,2 & 47,7 & 226,9 \\
\hline 4 & Bojongloa Kaler & 0 & 0 & 212,2 & 212,2 \\
\hline 5 & Babakan Ciparay & 28,9 & 106,6 & 211,6 & 347,1 \\
\hline 6 & Andir & 29,5 & 34,7 & 163,3 & 227,5 \\
\hline 7 & Cicendo & 94,9 & 63,6 & 147,9 & 306,5 \\
\hline 8 & Bandung Kulon & 4,1 & 74,3 & 246,9 & 325,3 \\
\hline 9 & Sukajadi & 206,3 & 66,6 & 120,2 & 393,1 \\
\hline & Jumlah & 871,7 & 660,1 & 1343,2 & 2875 \\
\cline { 2 - 5 } & Prosentase & 30,4 & 22,9 & 46,7 & 100 \\
\hline
\end{tabular}

Sumber: Hasil Pengolahan, 2008.

Berdasarkan Tabel 12 dapat diketahui bahwa di daerah penelitian $46,7 \%$ atau seluas 1343,2 Ha termasuk kategori rentan, 30,4\% atau seluas 871,7 Ha termasuk kategori tidak rentan, dan 22,9\% atau seluas 660,1 Ha termasuk kategori agak rentan. Kecamatan yang paling luas kategori rentan, yaitu Bandung Kulon (246,9 Ha), Bojongloa Kaler (212,2 Ha), Babakan Ciparay (211,6 Ha), Coblong (163,3 Ha) dan Cicendo (147,9 Ha). Kecamatan yang paling luas kategori agak rentan, yaitu Coblong (174,5 Ha), Babakan Ciparay (106,6 Ha), Cidadap (77,2 $\mathrm{Ha})$, dan Bandung Kulon (74,3 Ha). Kecamatan yang paling luas kategori tidak rentan, yaitu Sukasari (281,7 Ha), Sukajadi (206,3 Ha), Coblong (124,4 Ha), dan Cidadap (101,9 Ha). 


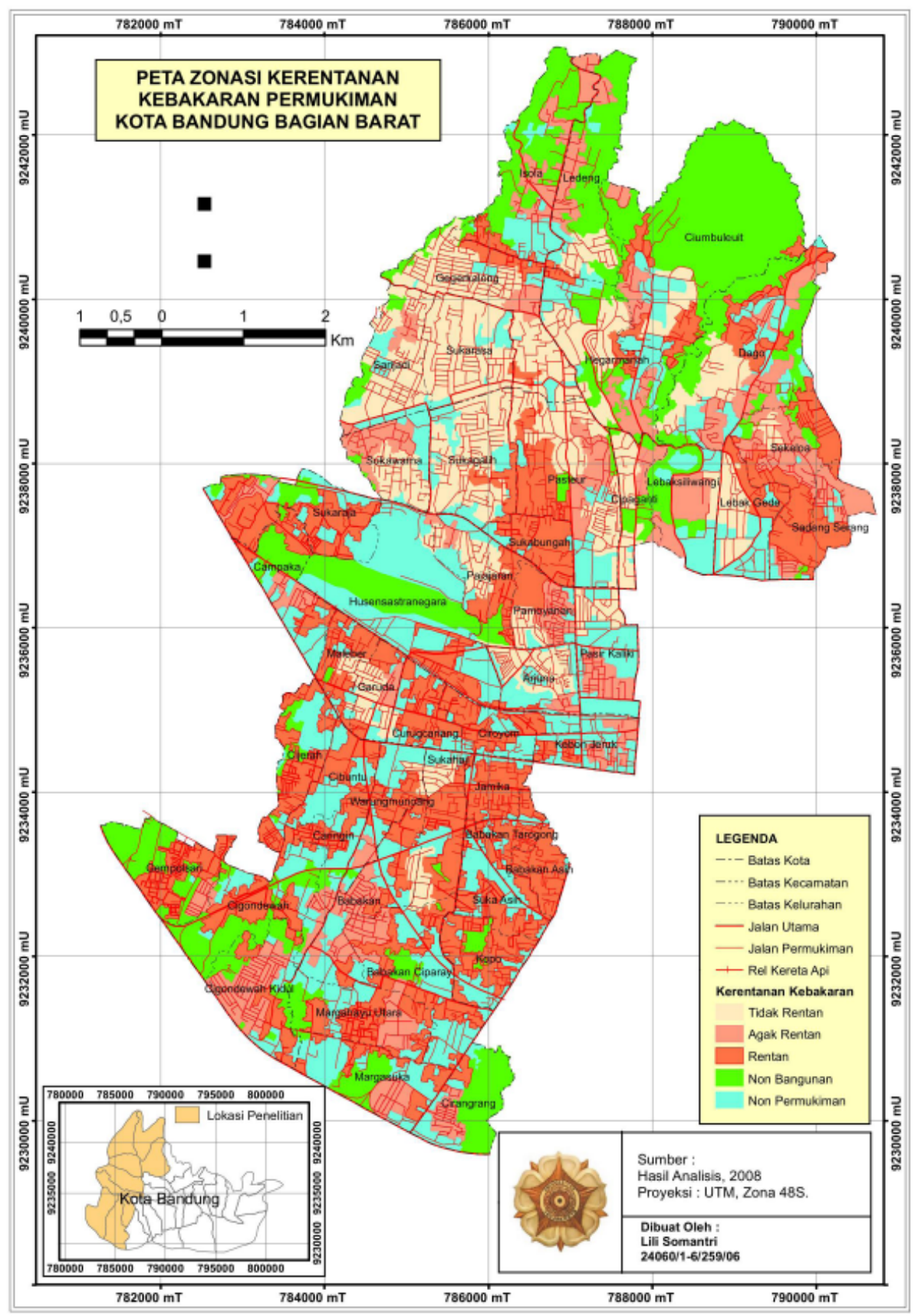

Gambar 3 Peta Zonasi Kerentanan Kebakaran Permukiman

Jika dilihat per kecamatan, Kecamatan Andir 71,8\% rentan terhadap kebakaran, 15,25\% agak rentan terhadap kebakaran, dan 12,9\% tidak rentan terhadap kebakaran. Kelurahan yang paling rentan di Kecamatan Andir, yaitu 
Ciroyom, Curugcariang, dan Maleber. Kecamatan Babakan Ciparay 60,9\% rentan terhadap kebakaran, 30,7\% agak rentan terhadap kebakaran, dan 8,3\% tidak rentan terhadap kebakaran. Kelurahan yang paling rentan kebakaran di Kecamatan Babakan Ciparay, yaitu Babakan Ciparay, Margahayu Utara, dan Sukahaji. Kecamatan Bandung Kulon $75,9 \%$ rentan terhadap bahaya kebakaran, 22,8\% agak rentan terhadap kebakaran, dan 1,2\% tidak rentan terhadap kebakaran. Kelurahan yang paling rentan terhadap bahaya kebakaran, di Kecamatan Bandung Kulon, yaitu Cijerah, Gempolsari, dan Cigondewah. Kecamatan Bojongloa Kaler, 100\% termasuk kategori rentan terhadap kebakaran yang meliputi Kelurahan Babakan Asih, Kopo, Suka Asih, Babakan Tarogong, dan Jamika. Kecamatan Cicendo 48,2\% termasuk kategori rentan, $30,9 \%$ tidak rentan, dan 20,8\% termasuk kategori agak rentan. Kelurahan yang paling rentan, yaitu Sukaraja, Pajajaran, dan Husensastranegara. Kecamatan Cidadap 44,9\% termasuk kategori tidak rentan terhadap kebakaran, 34\% termasuk kategori rentan, dan $21 \%$ termasuk rentan. Kelurahan yang paling rentan adalah Ciumbuleuit.

Dari semua kecamatan yang ada di daerah penelitian, Bojongloa Kaler merupakan kecamatan yang seluruh wilayahnya (100\%) termasuk kategori rentan terhadap kebakaran. Hal ini karena Kecamatan Bojongloa kaler 91,4\% wilayah termasuk kategori padat dan $8,1 \%$ agak padat, 93,6\% polanya tidak teratur, 91,4\% jenis atapnya kategori sedang (ada bahan yang mudah terbakar), $98,3 \%$ lokasinya jauh dari jalan utama, 98,3\% lokasinya jauh dari sumber air, 93,6\% kondisi jalannya sempit (>3 meter) untuk akses masuk, 93,6\% kondisi jalannya agak baik, 97,8\% termasuk pada kategori sedang $(20 \%-50 \%$ yang berlangganan ke PLN), 99,4\% lokasinya jauh dari hidran dan 100\% lokasinya jauh dari tandon air, 100\% wilayahnya tidak dilengkapi oleh APAR dan 97,8\% wilayahnya tidak terjangkau oleh fasilitas APAB.

\section{SIMPULAN}

Berdasarkan hasil pemetaan kerentanan kebakaran di daerah penelitian dibagi atas tiga kelas, yaitu rentan, agak rentan, dan tidak rentan. Di daerah penelitian $46,7 \%$ atau seluas 1343,2 Ha termasuk kategori rentan, 30,4\% atau seluas 871,7 Ha termasuk kategori tidak rentan, dan 22,9\% atau seluas 660,1 Ha termasuk kategori agak rentan. Kecamatan yang paling luas kategori rentan, yaitu Bandung Kulon, Bojongloa Kaler, Babakan Ciparay, Coblong, dan Cicendo. Kecamatan yang paling luas kategori agak rentan, yaitu Coblong, Babakan Ciparay, Cidadap, dan Bandung Kulon. Kecamatan yang paling luas kategori tidak rentan, yaitu Sukasari, Sukajadi, Coblong, dan Cidadap.

Permukiman yang rawan terhadap kebakaran, dicirikan dengan kondisi permukimannya merupakan daerah padat, dengan pola bangunan permukiman tidak teratur, lokasi permukimannya jauh dari jalan utama dengann kondisi lebar jalan masuk yang sempit, bahan bangunannya termasuk kategori non permanen sehingga agak mudah terbakar, banyak rumah yang tidak 
berlangganan listrik ke PLN sehingga dalam pemasangan listrik asal-asalan, tidak dilengkapi fasilitas APAR dan APAB, dan lokasinya jauh dari sumber air (sungai, danau), hidran, dan tandon air.

Adapun saran-sarannya, yaitu embangunan fasilitas-fasilitas pemadam kebakaran, terutama pada daerah-daerah yang rentan kebakaran, seperti tandon air yang secara khusus untuk pemadaman bukan dari tandon air yang tersedia di hotel atau bangunan bertingkat. Perawatan fasilitas hidran harus terus dilakukan jangan sampai dibiarkan rusak dan tidak berfungsi serta kondisi airnya harus tetap stabil. Setiap rumah harus dilengkapi dengan fasilitas APAR atau dalam setiap RT harus tersedia fasilitas APAB. Perlu ditambahkan mobil unit-unit pemadam kebakaran mengingat jumlah penduduk yang banyak. Semua warga harus diprogramkan untuk diberikan penyuluhan dan pelatihan mengenai cara pencegahan dan penanggulangan terhadap bahaya kebarakan.

\section{DAFTAR PUSTAKA}

Digital Globe. (2007). QuickBird Imagery Products (Product Guide). DigitalGlobe, Inc., Longmont.

Ditjen Cipta Karya. (1980). Pedoman Pelaksanaan Perintisan Perbaikan Lingkungan Permukiman Kota. Jakarta: Laporan. Ditjen Cipta Karya.

Gunawan, T. (2005). Teknologi Penginderaan Jauh Dalam Pengelolaan Sumberdaya Air. Pidato Pengukuhan Guru Besar pada Fakultas Geografi Universitas Gadjah Mada. Yogyakarta.

http//: www.rsgisforum.net.htm diakses tanggal 4 maret 2008

Naibaho, J.V. (2004). Identifikasi Jaringan Jalan Pada Data Satelit Quickbird Dengan Teknik Filtering (Studi Kasus Bandung). Bandung: Jurusan Teknik Geodesi FTSP-ITB.

Suharyadi. (2000). Pemodelan Zonasi Kerentanan Kebakaran dengan Memanfaatkan Ortho-foto Dijital (Kasus di Sebagian Kecamatan Gondomanan Yogyakarta). Yogyakarta: Fakultas Geografi Universitas Gadjah Mada.

Suharyadi. (2001). Penginderaan Jauh untuk Studi Kota. Yogyakarta: Fakultas Geografi Universitas Gadjah Mada.

Sutanto. (1986). Penginderaan Jauh. Yogyakarta: Gadjah Mada University Press. 